\title{
PYLKINGTON'S CASE AND ITS SUCCESSORS
}

At Easter Term in the Thirty-third year of the reign of Henry the Sixth (1454-55) a novel case was brought before the Judge's sitting in the Exchequer Chamber.' It was the year of the first battle of St. Albans and the factions of the red and white roses were engaged in a saguinary struggle for the custody of the incompetent monarch, but the courts sat undisturbed at Westminster listening to arguments and giving judgment as unconcernedly as in happier times. Chief Justice Fortescue presented the facts. By a special act of Parliament passed at a session in the spring of I450, John Pylkington was required to appear on a charge of rape. Pylkington did not obey but, when taken prisoner and incarcerated in the King's Bench prison in the custody of the Marshall, appeared by counsel to attack the validity of the act, showing that the bill, as it passed the Commons, required "that the said John surrender himself before the feast of Pentecost next ensuing," while, as it passed the Lords, he was to appear "before the feast of Pentecost which shall be in I45I." It was argued that "because the Lords granted a longer day than was granted by the Commons, in which case the Commons ought to have the bill returned to them and assent to the grant of the Lords but it was not so; wherefore the act seems void." The court then sent for Kirkby, the Master of the Rolls and Fauxes, the clerk of Parliament to get their opinion on the Parliamentary procedure, which was explained at length by Kirkby who thought the act was not good. Fauxes, however, narrated the circumstances that led to the seeming discrepancy. According to his account the bill was introduced in the Commons after the feast of the Pentecost in $145^{\circ}$ with the intention that the proclamation should last until the feast of the Pentecost next ensuing, but because at that time every act was dated as of the first day of the

' Y. B. 33 Hen. VI, 17, pl. 8. 
session the Lords inserted $145 \mathrm{I}$ to make the bill conform to its true intent. Chief Baron Illingsworth ${ }^{2}$ and Mr. Justice Markham thought the act invalid as it appeared in the file, and Markham added a criticism of the legislative methods. "Truly this is a perilous thing: for the court of Parliament is the highest court that the King has, and indeed for every manner of thing or act that is material and done there, the reason should be enrolled." Chief Justice Fortescue said: "This is an Act of Parliament and we wish to be well advised before we annul any act made in Parliament and peradventure the matter should wait until the next Parliament, until we can be certified by them of the certainty of the matter."

The case was taken under advisement and no final judgment is reported. In fact, upon the precise point involved, that is, whether informalities in the final agreement of both houses will vitiate a statute, no decision of a - British court has ever been obtained, although in two modern instances irregularities of this character have been corrected by declaratory legislation. ${ }^{3}$ But the larger question, whether an act, purporting to have received the assent of King, Lords and Commons, duly enrolled in Parliament and Chancery is conclusive upon the courts, apparently first mooted in this case, has troubled. the courts of the New World, undiscovered when Pylkington's fate was left hanging in the balance by a reporter more interested in law than in results. One may wonder, indeed, what turn the learned Chief Justice, author of De Landibus Legum Angliae, would have given to his remarks had he realized that the case would be cited as a precedent four hundred and fifty years later.

In Great Britain Parliament is supreme and the courts are not competent to go behind its enactments. "An act of Parliament," said Lord Chief Justice Holt, "can do no until 1462 .

${ }^{2} \mathrm{He}$ is so described in the case but Foss says he was not Chief Baron

${ }^{3}$ Hardcastle believes the case would be followed, Statutory Law (3 ed.). See also May's Parliamentary Practice (r2 ed. 402). 
wrong though it may do several things that look pretty odd." "We sit here," said Mr. Justice Willes, "as servants of the Queen and the legislature. Are we to act as regents over what is done by Parliament with the consent of the Queen, Lords and Commons? I deny that any such authority exists. If an act of Parliament has been obtained improperly, it is for the legislature to correct it by repealing it; but so long as it exists as law, the Courts are bound to obey it." 5 Thus, an act cannot be impeached on the ground that its passage was procured by fraud. 6 Of course, as the assent of King, Lords and Commons is essential to constitute an act of Parliament, except in the instances provided for in the Parliament Act of $19 I I,{ }^{7}$ the absence of the assent of one of these constituent branches of the legislature will prevent a bill from ever taking effect as a statute. Such was the case in 1488 when a bill of attainder was assented to by King and Lords, but not the Commons. All the Judges held it was not an act. ${ }^{8}$ But an act duly assented to and enrolled in the records of Parliament and in Chancery, it may safely be asserted, would be held conclusive by the courts which would refuse to examine the journals of either house to see whether the act had been passed in accordance with accepted legislative rules. Such was the conclusion of the chancellor and judges in the case of the King v. Arundel ${ }^{9}$ in 1616 , where it was held that the journals of Parliament could not destroy or weaken an act which "being a high record could be tried only by itself." But if the record of the act "carry its death wounds in itself," then it was true that the "parchment, no, nor the great seal will not serve." As put by Lord Campbell in a modern

1 City of London v. Wood, 12 Mod. 669 (1700).

Lee v. Bude \& T. J. R. Co.; L. R. 6 C. P. 576 (187I).

6 Stead v. Carey, I C. B. 496 (1845); Waterford Ry. Co. v. Logan, I4 Q. B. 672 (1850); Labrador Co. v. Green, (1893) A. C. I04; London \& C. L. I. A. Co. v. Rural Municipality of Morris, 7 Manitoba 128 (1890); Sunbury \& E. R. R. Co. v. Cooper, 33 Pa. 278 (1859); Carr v. Coke, II6 N. N. 223 (1895). 7 I \& 2 Geo. v. Ch. I3.

8 Y. B. 4 Hen. VII, 18. See also the Prince's Case, 8 Co. 28 (I605); College of Phisitians v. Cooper, 3 Keb. 587 (1675).

9 Hobart Io9, Case 132 (1616). 
case: "All that a court of justice can do is to look to the Parliamentary roll; if from that it should appear that a bill has passed both houses and received the royal assent, no court of justice can inquire into the mode in which it was introduced into Parliament, nor into what was done previous to its introduction, or what passed in Parliament during its progress in its various stages through both houses." 10

In the United States the conflict of opinion on this subject is due to divergent views as to the functions of the courts in acting as a check upon the legislatures, under the prevalent constitutional system. Fundamentally the question is one of evidence as has been learnedly pointed out."11 The enrolled act is but a solemn certificate of the enactment of the law by the legislature, the legislative journals are but official statements of what passed in the respective houses. Whether the enrolled act shall be conclusive as against the journals is merely a question as to whether an official statement of one character shall prevail as against another of less dignity. But in most instances the discussion has taken a broader range and is concerned largely with the problem whether or not it is the duty of the courts to go behind the enrollment and pass upon the validity of an act, as. tested by the proceedings on its passage, when the legislative procedure is prescribed by the constitution.

Not until the middle of the nineteenth century was the issue fairly presented; other and more pressing problems had the right of way. The power of the courts to pass on the constitutionality of legislation had to be established; the power of the legislatures to interfere with the judgments of courts denied. Out of the struggle the courts emerged supreme, in fact as well as name, and the victory was reassuring to those who viewed with anxiety the steady deterioration in public morality that accompanied and.succeeded the Jacksonian era. As legislators became less trustworthy, more and more it became the custom to hedge

${ }^{10}$ Edenburgh \& D. R. Co. v. Wanchope, 8 Cl. \& F. 7IO (1842). See also Bradlaugh v. Gossett, (I884) I2 Q. B. D. 271 .

il Wigmore on Evidence, sec. 1350 . 
them about with constitutional restrictions which applied not only to the form and content of legislation but to the practice and methods of legislative bodies as well; and, by way of vicious circle no doubt, the mechanical safeguards upon political action led to a false feeling of security and a less careful choice of representatives. The state constitutions in force at the adoption of the constitution of the United States ${ }^{12}$ do not contain the elaborate checks upon legislative procedure to be found in the constitutions of today, but the rudiments of some of these well known restrictions were present. In New Hampshire and Pennsylvania, for example, the journals were to be published and, on motion, the yeas and nays taken; in Georgia all laws were to be three times read, each reading to be on different and separate days, except in cases of great necessity and danger. But as the various constitutions underwent revision these restrictive clauses were strengthened and enlarged, although it was some time before their effect came to be felt in judicial decisions.

As might well be suspected, the journal entry heresy had its origin in New York in the days when the State Senate constituted the Court of Errors. In Warner v. Beers, ${ }^{13}$ the general banking law of 1838 was sustained although it was denied that it had received the assent of two-thirds of the members of the legislature as the constitution required in the case of acts creating altering or renewing corporations. The chancellor expressed his doubt as to whether a court could institute an inquiry into the mode in which a law was passed which was signed by the governor, and duly certified by the Secretary of State. Senator Verplanck, however, could not see why the courts were not bound to receive as the conclusive legal evidence for public legislative acts the official journals required to be kept by law. A similar question arose in Purdy v. People, ${ }^{14}$ where the ques-

${ }^{12}$ The Constitutions of the Several States (1785). See also Article I, Sec. 5 , cl. 3 of the Constitution of the United States.

${ }_{13} 23$ Wend. 103 (1840).

142 Hill 3 I (N. Y. 184I); Purdy v. People, 4 Hill 384 (N. Y. I842). See also De Bon v. People, I Den. 9 (N. Y. 1845 ) overruled in Gifford v. Livingston, 2 Den. 380 (N. Y. 1845 ). 
tion was whether an act of 1840 excluding aldermen of the city of New York from sitting in the court of general sessions was within the constitutional provision requiring the assent of two-thirds of the members of the legislature. The principal point in dispute was whether the act was of the character that required a two-thirds vote. The attorney general conceded, that the act was not passed by the votes of two-thirds of the members, but there was considerable discussion of the difficulties involved in an inquiry into the validity of an act. Mr. Justice Bronson, in the Supreme Court, did not venture beyond suggesting that the court must, when called on to do so, go behind the "printed statute book." In the Court of Errors Chancellor Walworth thought that the certificates of the presiding officers in the House should be considered the legal evidence that the act had received the required assent. No exception can be taken to these views, as they do not carry the inquiry back of the enrolled bill. But Senators Paige and Franklin referred to the journals of the Senate and Assembly as evidence of the manner in which the act was passed. Strictly speaking, these cases do not stand for the broad principles for which they have been cited in other jurisdictions but the dicta they contained looked in the direction of greater control over legislative action. "We live," said Mr. Justice Bronson, "under a government of laws, reaching as well to the legislative as to the other branches of the government; and if we wish to uphold and perpetuate free institutions, we must maintain a vigilant watch against all encroachments of power, whether arising from mistake or design, and from whatever source they may proceed." Twenty years later the orthodox view was upheld by the Court of Appeals in People v. Develin ${ }^{15}$ and New York is now counted among the States that will not permit a duly enrolled statute to be impeached by the journals.

${ }^{15} 33$ N. Y. 269 (1865). See also People v. Purdy, 54 N. Y. 276 (1873); Helm v. Day, 134 N. Y. 770 (I912). In Matter of N. Y. I. L. Bridge Co., 148 N. Y. 540 (1896) the journals were looked at to supplement the certificates of the presiding officers. Accord, Matter of Stickney, 185 N. Y. 107 (1906). The certificates of the presiding officers are now conclusive by law, 4 Consolidated Laws N. Y. (1917) P. 474r; Laws 1909, ch. $37, \$ 40$. 
With the turn of the half century a rapid succession of cases disclosed the divergent views entertained toward the problem. In I849 the Supreme Court of Errors of Connecticut, two judges doubting, refused to go behind the revised statutes to inquire into the proceedings of the committee on revision. ${ }^{16}$ But in Spangler v. Jacoby, ${ }^{17}$ the Supreme Court of Illinois, in I853, declared that it was clearly competent to show from the journals of either branch of the legislature, that a particular act was not passed in the mode prescribed by the Constitution, and thus defeat its operation altogether. As the first clear and unequivocal adoption of the journal entry rule the case is entitled to be regarded as the leading one on that side of the argument. The bill in question was signed by the speakers of both houses and by the governor, but the journal of the House of Representatives failed to show that it was ever put on final passage in that house and the Constitution required that on the final passage of all bills, the vote should be by ayes and noes, and should be entered on the journal. The act was held null and void. The journal, said Chief Justice Treat, "is the evidence of the action of the house, and by it the act must stand or fall. It certainly was not the intention of the framers of the Constitution, that the signatures of the speakers and the executive should furnish conclusive evidence of the passage of a law." The presumption, the court went on to say, was that an act so verified was law, but when the journal failed to show that the act was passed in the mode prescribed by the Constitution the presumption was overcome. This is an extreme view, in a number of states accepting the journal entry rule the silence of the journals raises no presumption against the validity of the act. ${ }^{18}$ But the precedent set in such an important jurisdiction has had, no doubt, great influence in establishing the general doctrine it favors. In the 1857

16 Eld. v. Gorham, 20 Conn. 8 (I849).

17 I4 Ill. 297 (I853). Accord, Turley v. Logan County, I7 Ill. I52 (I855).

18 State v. Peterson, 38 Minn. I43 (I888); Chesney v. Clintock, 6r Kan. 94 (I899); State v. Frank, 6o Neb: 327 (I900). In re Drainage Dist., 26 Idaho 3 I I (I9I4). 
edition of his work on Statutory construction, Sedgwick stated that it would seem that the journals might be consulted, ${ }^{19}$ and in $185^{8}$ Minnesota and New Hampshire took that ground. ${ }^{20}$

On the other hand, the contrary doctrine was maintained in decisions rendered in I856 in Mississippi and Missouri. In Green v. Weller ${ }^{21}$ after a very full argument the majority of the Court refused to follow the dicta in Purdy v. People, the courts, said Mr. Justice Handy, have no more power to transcend their jurisdiction, than has the legislative department of the government. Chief Justice Smith vigorously dissented.

In Pacific Railroad v. The Governor, 22 it was held that the certificates of the presiding officers of the two Houses of Assembly that a statute had passed by a constitutional majority could not be impeached by the journals showing a departure from the forms prescribed by the Constitution. The question said the court, whether a law on its face violates the Constitution, is very different from that growing out of non-compliance with the forms required in its enactment. To go behind the law would be an inquisition into the conduct of the general assembly the frequent exercise of which would lead to endless confusion. Some twenty years later Missouri reversed its position on this point following what was then the current of authority and attempting to distinguish the earlier case on the ground that changes had been made in the constitution since it was rendered. ${ }^{23}$

Strong support to the enrolled bill theory was given in the next decade by the California case of Sherman $v$. Story ${ }^{24}$ and the Indiana case of Evans v. Browne, ${ }^{25}$ in each instance overruling prior decisions. Of the same period is Pangborn v. Young ${ }^{26}$ in the Supreme Court of New Jersey,

${ }^{19}$ Sedgwick on Statutory Construction (I ed.). Chap. 4 .

20 Opinion of the Justices, 35 N. H. 579 (1858); Board of Supervisors of Ramsey Co. v. Heenan, 2 Minn. 330 (1858).

${ }^{21} 32$ Miss. 650 (1856). Accord Ex parte Wren, 63 Miss. 512 (1886).

2223 Mo. 353 (1856) distinguishing State v. McBride, 4 Mo. 23 (1836).

${ }^{23}$ State v. Mead, 71 Mo. 266 (1879).

21 30 Cal. 253 (1866) overruling Fowler v. Pierce, 2 Cal. I65 (1852).

${ }_{25} 30$ Ind. 514 (I869) overruling Skinner v. Deming, 2 Jud. 558 (I85I).

${ }^{26} 32$ N. J. L. 29 (I866). 
sometimes cited as the leading case on this side; a position due to the learned and convincing opinion of Chief Justice Beasley in which the principles involved are traced back to the year books. He calls attention to the careless way the journals are kept and observes that if the laws are to be tested by a comparison with the journals the stability of all written law will be shaken to its foundations. The journal moreover would be no check on the actions of those who keep it when a violation was intentional. To the argument that the legislature might wilfully infringe constitutional prescriptions the answer was that "the judicial and legislative departments are made co-equal, and that it nowhere appears that one has the right of supervision over the other." Cogent as the reasoning of the court was, it did not accord with public feeling at the time. Even the legislature of New Jersey seemed unwilling to assume full responsibility for its acts, for in 1873 an act was passed providing that the Supreme Court, on petition of the attorney general or two or more citizens setting forth their reasons for believing an act was not duly passed as required by the Constitution, was empowered to inquire in a summary way into the circumstances and if satisfied that the law was not duly and constitutionally passed, to decree the same or any part thereof null and void. ${ }^{27}$ Such a law indicates the high water mark of judicial power. That it has been tactfully administered by the court in the spirit of Pangborn v. Young ${ }^{28}$ does not detract from its significance. It was a period of low political morality when legislatures were distrusted and the courts looked upon by the public as the sole guardians of the Constitution. This point of view is reflected in the decisions. While in theory the legislative and judicial departments are co-equal it does not follow, it is said in a case upholding the journal entry rule, that the latter may not declare an act invalid which has been unconstitutionally passed. "Certainly the supreme power-the

27 Act of March 3, 1873, P. L. 27, Comp. Stat., p. 4978.

${ }^{28}$ See In re Iow, 88 N. J. L. 28 (I9I5). 
people-have the right to impose limitations upon the power of either; and no one will deny that the people, speaking through their fundamental law, may declare what shall be a prerequisite to a legislative act. If such power exists there must be some tribunal which has the right to determine whether the mandate of the constitution has been obeyed. Under our system of government where can such power be lodged except in the courts? If not there it is nowhere; and it necessarily follows that the legislature is above the law, greater than its creator, and the Constitution a vain and useless thing in so far as it seeks to impose restrictions upon the legislative department." 29 "A bill," said Chief Justice Cooley, "considered in the legislature, but not constitutionally passed, can never become a law by its being signed by the Governor and published with the statutes. That is too plain a proposition to need argument or illustration." That Judge Cooley, in his work on Constitutional Limitations, ${ }^{31}$ adhered to the journal entry rule, was a factor in producing that strong general tendency toward its adoption which long prevailed and was only checked in I89I by the decision in Field v. Clark. ${ }^{32}$

The Supreme Court of the United States for a long time had no opportunity to pass on this controverted question. In Gardner v. The Collector, ${ }^{32}$ it was held that whenever a question arose of the existence of a statute or the time when it took effect, which in this case was the point involved, as the enrolled act contained no other date of the president's approval than the day of the month, the court had liberty to resort to any source of infor mation including the journals. South Altoona v. Perkins was decided on Illinois law. ${ }^{34}$

${ }^{29}$ Rash v. Allen, I Boyce 444 (Del. I910). See also People v. Mehaney, 13 Mich. 48I (1865); Jones v. Hutchinson, 43 Ala. 72 I (1868); Union Bank v. Commissioners, II9 N. C. 214 (1896).

${ }^{30}$ Attorney General v. Joy, 55 Mich. 94 (1884).

31 Colley's Constitutional Limitations (6 ed.) I62. A number of cases rely on a quotation from this work alone.

32 I 43 U. S. 649 (I891).

336 Wall. 497 (U. S. 1867).

${ }^{34} 94$ U. S. $260(1876)$. Followed Wilkes Co. v. Coles, 180 U. S. 506 (1900); School District v. Chapman, 152 Fed. 887 (1907); United States v. Andem, 158 Fed. 996 (1908); Burlingham v. Teubern, 23 Fed. I014 (1914). 
In Field v. Clark ${ }^{35}$ suits were brought by importers to obtain a return of duties claimed to have been illegally exacted under the tariff act of $1890 .{ }^{36}$ The enrolled act was attested by the Speaker of the House and the Vice President and approved by the President, but it was alleged that the record of the proceedings in Congress showed that a section of the bill as finally passed was not in the enrolled act. Mr. Justice Harlan who delivered the opinion of the majority of the court, said that the respect due to co-equal and independent departments of the government required the court to accept as authentic bills which carriep on their face the solemn assurance by the legislative and executive departments that they were duly passed. The evils resulting from the recognition of such a principle would be far less than those that would result from a rule making the validity of enactments depend upon the manner in which the journals of the respective houses were kept. To what extent the validity of legislation might be affected by a failure to enter on the journal those matters expressly required to be entered by the constitution was unfortunately, and it would seem unnecessarily, left undecided, ${ }^{37}$ but the broad doctrine announced in Field v. Clark has been repeatedly approved in the Federal courts, ${ }^{38}$ and may be said to have turned the tide of opinion in favor of the enrolled act rule in a number of jurisdictions where the point was still unsettled.

It would unduly prolong the discussion to take up in detail the law of the various states. The cases have been collected and are easily accessible. ${ }^{39}$ In Ritzman v. Camp-

${ }^{35}$ I 43 U. S. 649 (I89I).

38 Act of Oct. I, 1890, 26 Stat. at L. 567 , c. 1244 .

${ }^{37}$ See further United States v. Ballin, I44 U. S. I (1892); Hubbard v. Lowe, 226 Fed. I35 (1915).

${ }^{38}$ Lyons v. Woods, I53 U. S. 649 (I894); Harwood v. Wentworth, I62 U. S. 547 (1896); Twin City Bank v. Neveker, 167 U. S. 196 (1897). Flint v. Stone Tracy Co., 220 U. S. 107 (1910).

${ }^{39}$ See Wigmore on Evidence, Vol. 2, sec. I350; Sutherland on Statutory Construction, Chap. 2; 40 L. R. A. N. S. I note, 9 Ann. Ca. 579 note, 20 Ann. Ca. 343; 47 Amer. St. Rep. 80I, 26 Amer. \& Engl. Enc. of L. (2 ed.) 555, 36 Cyc. I244. For Pennsylvania see Kilgore v. Magee, $85 \mathrm{~Pa}$. $40 \mathrm{I}$ (I877); Comm. v. Martin, I07 Pa. 185 (1884). 
bell ${ }^{40}$ the Supreme Court of Ohio has attempted a classification of the jurisdictions, finding that the enrolled bill controls in "the United States, California, Connecticut, Indiana, Iowa, Louisiana, Maine, Mississippi, Nevada, New Jersey, New York, North Carolina, Pennsylvania, Montana, Georgia, Kentucky, Utah, Oklahoma, South Carolina, Texas, North Dakota and South Dakota," while the journals control in "Alabama, Arkansas, Colorado, Florida, Illinois, Kansas, Maryland, Michigan, Minnesota, Missouri, Nebraska, New Hampshire, Oregon, Tennessee, Virginia, Washington, West Virginia, Wisconsin, and Wyoming." This arrangement represents the tendencies rather than the exact shades of opinion in these states and contains some errors. In Washington, for example, which is classed with the journal entry states, the enrolled bill has been held to control in one of the best reasoned opinions on this subject, ${ }^{41}$ while the enrolled bill doctrine credited to North Carolina is there qualified by exceptions.42 The Ohio Court gave it as their rule that they would consult the journals to ascertain whether the act had received a constitutional majority but would not inspect the journals for the purpose of establishing a discrepancy between the enrolled bill and the bill as it might appear from the journals. The court finds no cases in Arizona, Delaware, Idaho, New Mexico, Massachusetts, Rhode Island and Vermont. In Idaho, however, the journal entry rule is followed, ${ }^{43}$ and the same principle has recently been accepted in Delaware by a divided court.44 In New Mexico, on the other hand, the enrolled bill rule has been adopted. ${ }^{45}$ Recent cases in other jurisdictions do not indicate any decided change of view although there are many fine distinctions taken which merely emphasize the

${ }^{10} 93$ Ohio St. 246 (1915).

11 State v. Jones, 6 Wash. 452 (1893).

12 Compare Carr. v. Coke, II6 N. C. 223 (1895) with Union Bank v. Oxford, II9 N. C. 214 (1896); Salem v. Wachovia L. \& T. Co., I43 N. C. IIO (I906); Packing Co., 135 N. C. 62 (1904). 3 II (19I4).

${ }^{4}$ Cohn v. Kingsley, 5 Idaho 416 (1897); In re Drainage Dist., 26 Idaho (1917).

Rash. v. Allen, I Boyce 444 (Del. I9Io).

15 Kelly v. Marron, 2I N. M. 239 (I9I5); State v. Hall, 23 N. M. 422 
difficulty of maintaining an intermediate position. ${ }^{46}$ It is interesting to find references to Pylkington's case in several American decisions including Weeks v. Smith ${ }^{47}$ in Maine as late as I889. So precedents may survive.

The confusion in which the subject is involved is increased by the fact that many states have changed the rule more than once and in several instances where the judges have felt bound by precedent they have expressed their preference for the rule not adopted in their state. But is the extent of the controversy warranted by its intrinsic difficulty? It would not seem so. The argument that the enrolled bill rule invites fraud in the passage and certification of acts is answered by the fact that the opportunities for committing fraud will be far greater if the journals are allowed to control the act. Aside from any question of fraud it is well known that legislative journals are hastily and sometimes carelessly prepared, and to make them the ultimate test of validity offers new opportunities for the nullification of legislation honestly adopted. As Dean Wigmore puts it succintly, the court will be going as far wrong in repudiating an act based on proper votes falsified in the journal as it will be in upholding an act based on improper votes falsified in the enrollment. As the parol testimony of the members is not admitted to impeach an act it would seem that the courts have fixed an arbitrary limit to their duty in getting at the facts regarding legislative obedience. to constitutional mandates. The basis of the doctrine would seem to be that the courts are bound to enforce mandatory constitutional provisions as to legislation. But no court

4 Compare, purporting to support the enrolled bill doctrine, Parkinson v. Johnson, I60 Cal. 756 (I9II); DeLoach v. Newton, I34 Ga. 739 (1910); State v. Lynch, I69 Iowa I48 (I9I5); Vogt v. Beauchamp, I53 Ky. 64 (I9I3); Atchison T. \& S. R. Co., 28 Okla. 94 (I9II); State v. Sawyer, I04 S. C. 342 (1916); Kraposki v. Waskey, 33 S. D. 335 (I9I4); Home Tel. Co. v. Nashville, I I8 Tenn. I (I906); Harris Co. v. Hammond, 203 S. W. 445 (Tex. I918) with Butler v. Directors, 99 Ark. 100 (IgI2); Denver v. Rubridge, 51 Colo. 224 (I9II); People v. Leddy, 53 Colo. ro9 (I9I2); Amos v. Moseley, 77 So. 619 (Fla. 1917); Worthy v. Bush, 262 Ill. 560 (1914); Ridgely v. Baltimore, II9 Md. 567 (I9I3); Jessup v. Baltimore, I2I Md. 562 (I913); In re Opinion of Justices, 76 N. H. 601 (I911); Anderson v. Bowen, 77 W. Va. 89 (1916) contra; Woolfolk v. Albrecht, 22 N. D. 36 (I9II) question undecided.

478 I Me. 538 (1889). 
has suggested any adequate test to determine which constitutional regulations of legislative action are mandatory and which permissive. The distinctions that have been attempted are arbitrary and unconvincing. After all, as a practical matter, is it not well known that there are many provisions in the various constitutions, relating both to the executive and legislative departments, that the courts have never thought of undertaking to enforce? The traditional theory of our government is that each of the three departments-the executive, the legislative and the judiciaryare equal and each responsible to the people that it represents and not to the other departments of the government. The journal entry doctrine is based on a false theory. It assumes that the provisions of the constitutions relating to legislation have been placed under the guardianship of the courts rather than the legislatures which, presumably, are without sufficient integrity to insure the preservation of the constitutions. The true solution lies in a greater sense of responsibility on the part of the electors in the choice of competent and honest legislators rather than in building up mechanical checks upon their conduct, the supervision of which is left to the judiciary in violation of its true functions.

Looked at historically, this great group of conflicting cases is extremely interesting as presenting most distinctly one characteristic phase of American constitutional thought. In spite of our tripartite system of government, there lies deep in the minds of many a craving for unity of power; for undivided authority. Sovereignty must be monistic, not pluralistic. Such a state of feeling, natural enough when the commoner tendencies of philosophic thought are considered, tends from time to time to exalt now one, now another of the coördinate branches of the Government. In the twentieth century, it would seem, the tendency has been to extend the executive power. The journal entry doctrine was the product of that exaltation of the judicial power characteristic of the middle and late nineteenth cen- 
tury. The halo of the great Marshall illuminated many a. mediocre bench, while the misdeeds of legislators were very real. In playing their part in this movement the courts: were not conscious of exceeding their powers. On the contrary they believed, like the public, that they were the only bulwarks against political immorality. The tide turned, and the opening years of the twentieth century found public opinion adverse to the extension of the powers of the courts. through constitutional assumptions, and the courts to a large extent have consciously or unconsciously brought their methods into accord with public opinion. Had the question of going back of the enrolled bill to the legislative journals been postponed until today, the judges would probably. echo the words of Mr. Justice Markham in Pylkington's. case: "Verament ceo est paryllous chose."

University of Pennsylvania Law School.

Wm. H. Lloyd. 